$\xi=$ 不

\title{
Reservoir characterization and by-passed pay analysis of philus field in Niger delta, Nigeria
}

\author{
Lukman Ayobami Sunmonu ${ }^{1}$, Moruffdeen Adedapo Adabanija ${ }^{2}$, Theophilus Aanuoluwa Adagunodo ${ }^{1 *}$, \\ Adetunji Ayokunnu Adeniji ${ }^{3}$ \\ ${ }^{1}$ Department of Pure and Applied Physics, Ladoke Akintola University of Technology, Ogbomoso, Nigeria \\ ${ }^{2}$ Department of Earth Sciences, Ladoke Akintola University of Technology, Ogbomoso, Nigeria \\ *Corresponding author E-mail: taadagunodo@yahoo.com
}

\begin{abstract}
Hydrocarbon resources have become the most essential commodity contributing to any nation's growth and development in the recent years. For the past decades now, the quest for hydrocarbon resources has been increasing in an arithmetic rate that its supply can no longer meets the demand for its consumption today. In petroleum industry, seismic and well log analyses play a vital role in oil and gas exploration and formation evaluation. This study is aimed to effectively characterize the reservoirs and analyze the by-passed pay in Philus Field, Niger-Delta, Nigeria in order to look into the economic viability and profitability of the volume of oil in the identified reservoir(s). The faults in the study area trend in NW-SE direction and dip towards the south. Seven reservoirs were mapped on Philus field. A discovery trap and a by-passed (new prospect) trap were mapped out on the field. The petrophysical analysis showed that porosity of Philus field was 0.24. The volumetric analysis showed that the Stock Tank Original Oil in Place of discovery trap (Philus field) ranged from 1.6 to $43.1 \mathrm{Mbbl}$ while that of new prospect trap ranged from 18.1 to $211.3 \mathrm{Mbbl}$. It is recommended that the oil reserve of Philus field needs to be recalculated.
\end{abstract}

Keywords: By-Passed Pay; Niger Delta; Porosity; Reservoir Characterization; Structure Maps; Traps.

\section{Introduction}

The world demand for petroleum has continued to increase, as it remains very important to the economy and development of a nation. The high cost incurred in its exploration, makes it necessary for high level of perfection in the method adopted for its detection in all parts of the world. Nigeria, being one of the major oil producing nations in the world is also furnished with this vital resource. Hydrocarbon resources have become the most essential commodity contributing to any nation's growth and development in the recent years. For the past decades now, the quest for hydrocarbon resources has been increasing in an arithmetic rate that its supply can no longer meets the demand for its consumption today. In the world's economic market of this century, countries furnished with oil and gas resources have been rated as the most powerful in-terms of economic growth and development as they bear the most valuable commodity upon which the survival of the present generation is said to have been built-on.

Reservoir Characterization generally determine the gross volume within the trap that has the potential to hold hydrocarbons, the accuracy of reservoir estimation such as thickness and others Petrophysical parameters of each reservoir is a critical element in interpretation, estimation of reservoir properties such as Porosity, Water Saturation and others parameter from seismic and well logs data. During analysis, efforts focus on estimating subsurface physical properties of rock units which are important in hydrocarbon exploration and exploitation. The knowledge of reservoir characterization is an important factor in quantifying producible hydrocarbon (Schlumberger, 1989). Precisely reservoir characterization can be obtained from well logs especially using gamma ray and resistivity logs (Asquith, 2004). In other to map hydrocarbon reservoir, studies of geologic structure that can hold hydrocarbon in place must be considered. Due to the need to thoroughly evaluate prospects so as to determine optimal production strategies and also minimize risk that may be associated with hydrocarbon exploration has driven the development of an array of techniques which attempt to propagate log properties. One of such techniques in use is the deterministic and linear physical relationship between log properties and the corresponding seismic response of subsurface rock units (Muslime and Moses, 2011; Eshimokhai and Akhirevbulu, 2012).

Evaluation of by-passed pay is an important task in log analysis. This is when an overlooked trap (or a new exploration setting) is discovered after reasonable scanning of well(s) that have once been interpreted before. Understanding 'net pay' is paramount before attempting by-passed pay analysis. Net pay is an interval that can produce economically at today's prices, today's costs, and with today's technology. Uneconomic resources twenty-five years ago might be economic in the present time. Zones incapable of production just ten years ago can now be economic with horizontal wells and current hydraulic fracturing technology. The essential technique to identify by-passed zone is referred to as the resistivity porosity overlay, which has been widely used for over fifty years ago as a quick-look log analysis technique. By quantifying the approach in a petrophysical software package, it lends itself to recon style analysis. It eliminates judgment fatigue by normalizing all those variable $\log$ scales and sensitivities.

This study was aimed to effectively characterize the reservoirs and analyze the by-passed pay in Philus Field, Niger-Delta, Nigeria in order to look into the economic viability and profitability of the 
volume of oil in the identified reservoir(s). The specific objectives of the study include lithology identification from sand/shale baseline analysis, delineation of prospective horizons, identification of by-passed pay or new exploration opportunities, and computation of petrophysical parameters of all hydrocarbon bearing sands in Philus field, Niger Delta, Nigeria.

In the report of Anyiam et al. (2010), they determine the formation evaluation of an onshore of well KG-5, green field of Niger Delta, Nigeria. Their formation evaluation result showed that two reservoir zones contain oil while the remaining two were filled with water.

Adaeze et al. (2012) used well log and core data to evaluate Uzek well of Niger Delta, Nigeria. Their result showed that four reservoirs were present in Uzek well. Water saturation in Uzek well was low, thus, indicating high hydrocarbon saturation. Reservoir properties such as porosity $(\phi)$, fluid saturation, and net pay thickness were determined by them.

Egbai et al. (2012) used well log data to provide mathematical modellings for calculating hydrocarbon in-place of reservoir Reservoir lithology, structure properties, hydrocarbon in-place, and water saturation of the reservoir was calculated which in turn was used to calculate the hydrocarbon saturation.

Ameloko and Omali (2013) used 3D seismic data and four well $\operatorname{logs}$ in Z-field, Niger Delta, Nigeria to characterize reservoir and interpret structural seismic profile. A network of faults and four horizons A, B, C, and D were identified and mapped. Time and depth structure maps of the top of the reservoir of interest showed that the hydrocarbon bearing structure is a fault-assisted anticlinal dependent structure. Two distinct faults (F1 and F2) were revealed on the time and depth structure maps. However, a fault-network of other structures were also identified and interpreted on the seismic sections. The reservoir's quality in the Z-field Niger Delta ranged from moderate to good and were excellent in some distal reservoirs.

Ologe et al. (2013) used 3D seismic data to determine the subsurface structural features and retentive capacity of the reservoir for hydrocarbon in part of Aloo-field, Southwestern Niger-Delta, Nigeria. Three noticeable horizons were mapped in Aloo-field. The generated depth structure maps for all surfaces of interest showed subsurface features such as the geometry of the identified horizons. The dip of the mapped faults in Aloo-field corresponds to the growth fault pattern which improves trapping mechanism of hydrocarbon in the study area. They reported that the two principal structural trapping mechanisms present were growth fault and rollover anticline which are synonymous with Niger-Delta.

\section{Location and geology of the study area}

The Philus field, an onshore field in Niger Delta (figure 1) has total coverage of $243.8 \mathrm{~km}^{2}$. The Niger-Delta is situated in southern Nigeria (Figure 2) between latitudes $3^{0} \mathrm{~N}$ to $6^{0} \mathrm{~N}$ and longitude $5^{0} \mathrm{E}$ to $8^{0} \mathrm{E}$ (Nwachukwu and Chukwura, 1986; Oyedele et al., 2013). Niger-Delta lies mainly in the Gulf of Guinea to the Southwest of the Benue Trough and constitutes the most important Cenozoic construction in the South Atlantic. It is generally agreed that the modern Niger Delta is built on an oceanic crust.

The Niger-Delta till date remains the most economic and producing sedimentary basin in Nigeria by the virtue of the quantity of petroleum accumulations discovered and produced as well as the spatial distribution of the petroleum resources to the onshore, continental shelf through deep water terrains (Oyedele et al., 2013). The onshore Niger-Delta province is solely depicted with the geology of southwestern Cameroun and southern Nigeria as shown in Figure 3. The northern boundary is the Benin flank; an eastnortheast trending hinge line south of the West Africa basement massif. The northeastern boundary is defined by outcrops of the Cretaceous on the Abakaliki High and further east-south-east by the Calabar flank; a hinge line bordering the adjacent Precambrian. The offshore boundary of the province is defined by the Came- roon volcanic line to the east, the eastern boundary of the Dahomey basin (the eastern-most West African transform-fault passive margin) to the west, and the two kilometer sediment thickness contour or the 4000-meter bathymetric contour in areas where sediment thickness is greater than two kilometers to the south and southwest. The province covered $300,000 \mathrm{~km}^{2}$ with a geologic extent of the Tertiary Niger Delta (Akata-Agbada) Petroleum System (Tuttle et al., 1999).

The geology of the Tertiary section of the Niger Delta is divided into three Formations, representing prograding depositional facies distinguished mostly on the basis of sand-shale ratio (Short and Stauble, 1967; Doust and Omatsola, 1990; Kulke, 1995; Ameloko and Omali, 2013). They are namely Benin Formation, the Paralic Agbada Formation and Prodelta Marine Akata Formation. They range in age from Paleocene to Recent. The Benin Formation is a continental latest Eocene to Recent deposit of alluvial and upper coastal plain sands. It consists predominantly of freshwater baring massive continental sands and gavels deposited in an upper deltaic plain environment. The Agbada Formation consists of paralic siliciclastics, which underlies the Benin Formation. It consists of fluviomarine sands, siltstones and shales. The sandy parts constitute the main hydrocarbon reservoirs. The grain size of these reservoir ranges from very coarse to fine. The Akata Formation is the basal unit of the Tertiary Niger Delta complex. It is of marine origin and composed of thick shale sequences (potential source rock), turbidities sand (potential reservoirs in deep water and minor amount of clay and silt. Beginning in the Paleocene and through the Recent, the Akata Formation formed during low stands, when terrestrial organic matter and clays were transported to deep-sea water areas characterized by low energy conditions and oxygen deficiency (Stacher, 1995; Ameloko and Omali, 2013). It is the major source rock in the Niger Delta. The three lithstratigraphical units have been established in both the Onshore and continental Shelf terrains as the main petroliferous units in Niger Delta of Nigeria.

\section{Materials and methods}

The data used for the study comprised three-dimensional seismic data (SGY format), well log data (LAS format) and check shot data. Mathematical models and automated techniques were employed for the study. The tool employed was GeoGraphix software. The major logs used from well log data are gamma ray, resistivity $\log$ and porosity log. The gamma ray and resistivity logs were used to delineate lithofacies.

Well-to-seismic tie was done on Philus field, reservoirs were identified, faults and horizons mapping were done, seismic structural maps were produced whereby the structural traps of both the discovery trap and the by-passed pay named as new prospect trap were identified on depth structure maps. Petrophysical parameters and volumetric analysis of the discovery and new prospect traps were done. However, appraisal well was used for trap productivity of the new prospect.

Reservoir characterization analysis of by-passed pay can be done qualitatively and quantitatively. Qualitative interpretation is done by observing the shape and patterns of the log of interest.

The steps involved in quantitative interpretation include: Estimation of volume of shale using Equation (1).

$$
V_{S h}=\frac{G R-G R_{\text {clean }}}{G R_{S h}-G R_{\text {clean }}}
$$

Where: $\mathrm{V}_{\mathrm{Sh}}=$ Volume of Shale, fraction; GR= Gamma ray reading from log, API;

$\mathrm{GR}_{\mathrm{Sh}}=$ Gamma ray reading from shale, API;

$\mathrm{GR}_{\text {Clean }}=$ Gamma ray reading from sandstone formation, API

Average porosity and effective porosity were calculated using Equations (2) and (3). 


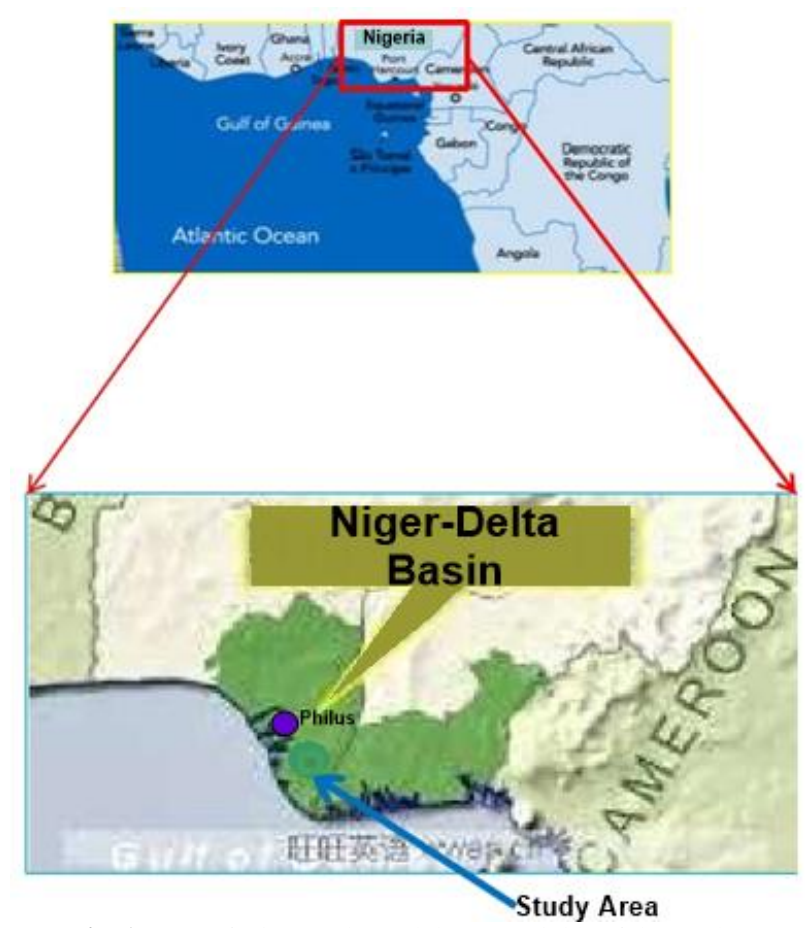

Fig. 1: Map of Niger-Delta and the Two Fields of the Study.

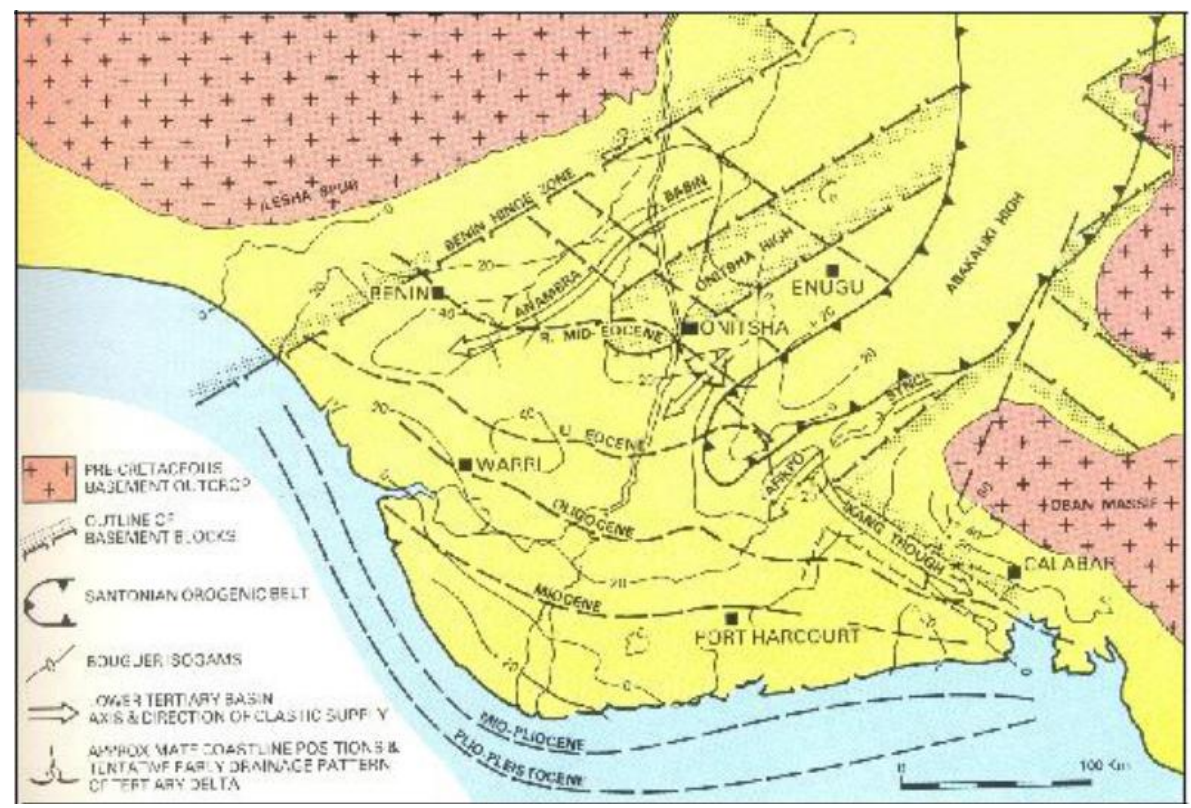

Fig. 2: Geological Map of Niger-Delta (after Oyedele Et Al., 2013). 


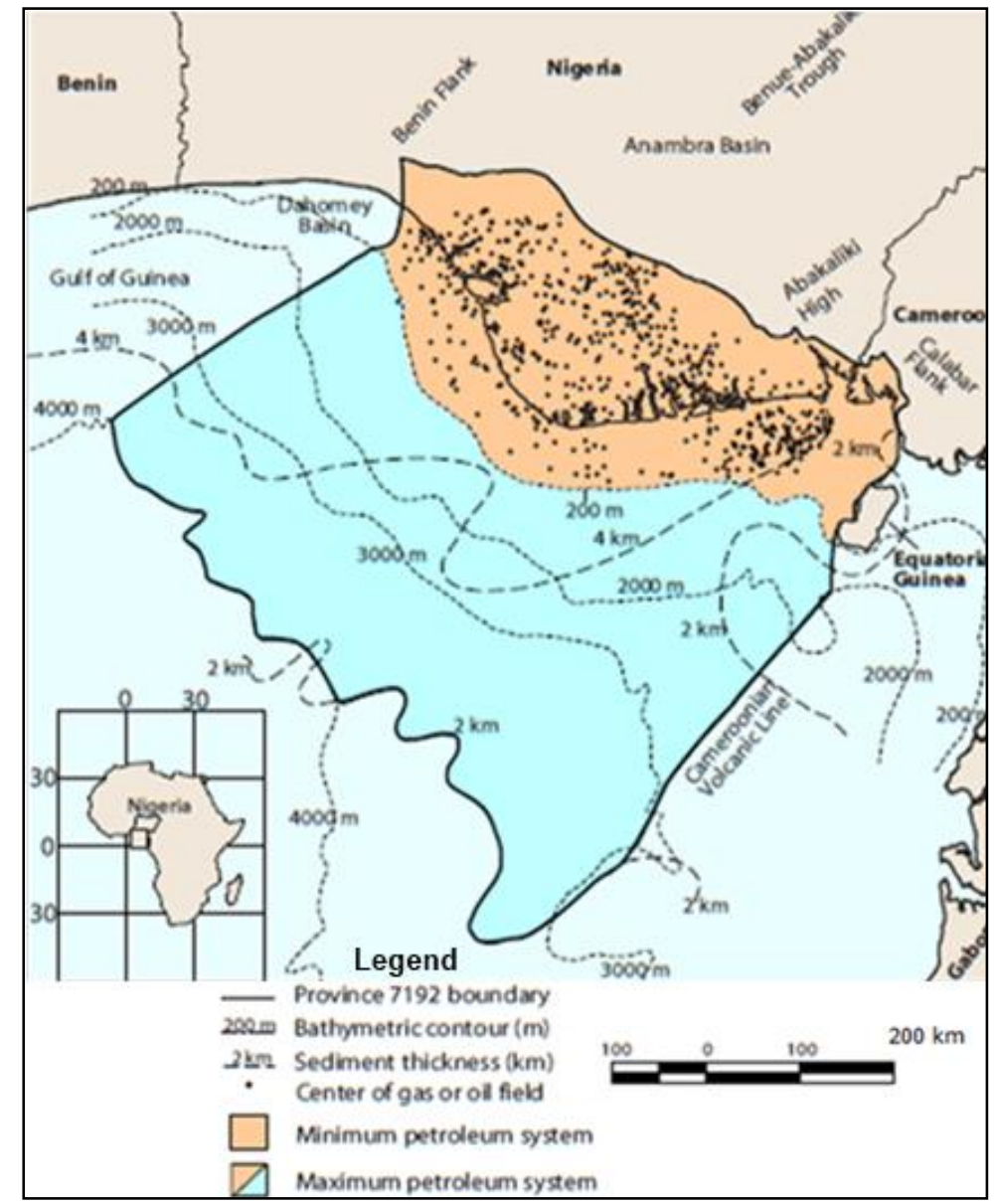

Fig. 3: Map of Nigeria Showing Province Outline. Source: Tuttle Et Al. (1999).

$\emptyset_{\mathrm{A}}=\frac{\emptyset_{\mathrm{D}}+\emptyset_{\mathrm{N}}}{2}$

Where: $\emptyset_{A}=$ Average porosity; $\emptyset_{\mathrm{D}}=$ Density derived porosity; $\emptyset_{\mathrm{N}}=$ Neutron porosity (from log)

$\emptyset_{\mathrm{E}}=\emptyset_{\mathrm{A}} \times\left(1-\mathrm{V}_{\mathrm{Sh}}\right)$

Where: $\varnothing_{\mathrm{E}}=$ Effective porosity; $\varnothing_{\mathrm{A}}=$ Average porosity; $\mathrm{V}_{\mathrm{sh}}=\mathrm{Vol}-$ ume of shale.

Saturation of hydrocarbon and hydrocarbon pore volume were estimated based on Equation (4) and (5).

$\mathrm{S}_{\mathrm{hc}}=1-\mathrm{S}_{\mathrm{w}}$

Where: $\mathrm{S}_{\mathrm{hc}}=$ hydrocarbon saturation, $\% ; \mathrm{S}_{\mathrm{w}}=$ water saturation.

$\mathrm{HCPV}=\emptyset \times\left(1-\mathrm{S}_{\mathrm{w}}\right)$

Original oil in place can be estimated using equation (6)

OOIP $=7758$ X GRV X NTG X Porosity X (1-Water Saturation)

Where: $7758=$ Conversion factor from acre-ft to barrel; NTG $=$ Net to Gross

Gross Rock Volume (GRV) or Net Volume $=\mathrm{h} \mathrm{X} \mathrm{A}$

Where: $\mathrm{h}=$ Pay-thickness from Petrophysics; $\mathrm{A}=$ Area from 3-D Seismic interpretation

However, Stock Tank Original Oil in Place (STOOIP) was determined using equation (8)

STOOIP $=$ OOIP $\div$ Boi
Where: Boi $=$ Oil Formation Volume Factor/Shrinkage Factor. Assumed Boi of 1.2 was used for the study.

Therefore Oil Reserve is given by equation (9).

Oil Reserve $=$ STOOIP X Oil Recovery Factor $\left(\mathrm{RF}_{\mathrm{o}}\right)$

\section{Results and discussions}

\subsection{Reservoir mapping, faults and horizons interpreta- tion}

A basemap of Philus field which covered an area extent of 243.8 $\mathrm{km}^{2}$ was presented on Figure 4. A single well has been the only well (Philus 1) drilled on the study area for exploration and production. 


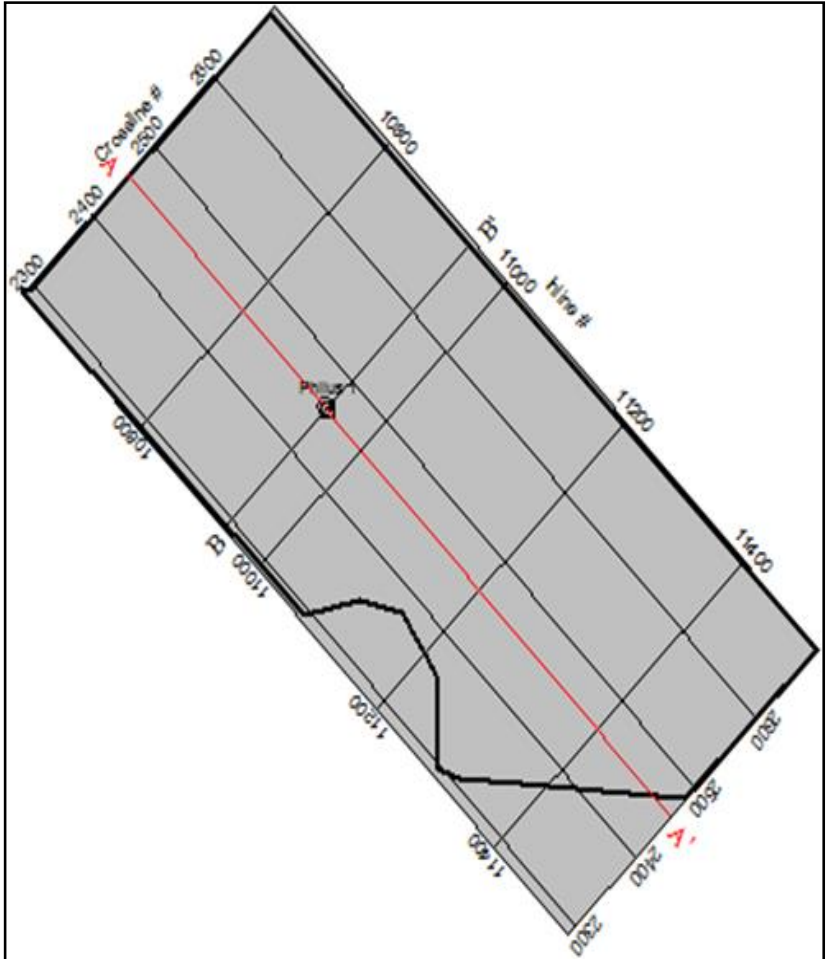

Fig. 4: Basemap of Philus Field Showing Well Location of Philus 1 and Seismic Lines.

Seven reservoirs (reservoirs A to G) were mapped out on Philus field (Figure 5). Since only one well is a producing well on Philus field, the reservoirs were only mapped without been correlated with other wells. The depths to the reservoir Top of Philus field are as follow: reservoir A Top is $8850 \mathrm{ft}(2681.8 \mathrm{~m})$, reservoir B Top is $9030 \mathrm{ft}$, reservoir C Top is $9180 \mathrm{ft}$, reservoir D Top is 9282 $\mathrm{ft}$, reservoir E Top is $9875 \mathrm{ft}$, reservoir F Top is $10100 \mathrm{ft}$, and reservoir $\mathrm{G}$ Top is $12530 \mathrm{ft}$.

The strike orientation of the fault in Philus field trends towards NW-SE direction while the dip orientation tends towards south (Figure 6). Figures $7 \mathrm{a}$ and $7 \mathrm{~b}$ shows the inline and crossline of interpretetd horizons of Philus field respectively.

Generally, the fault is resulted to a gap on a structure map between the formations in the hanging walls and the downthrown blocks. It gives rise to effective hydrocarbon traps closed by an anticlinal structure. The horizons were used to generate the seismic structural maps (i.e. the time and the depth structure maps).

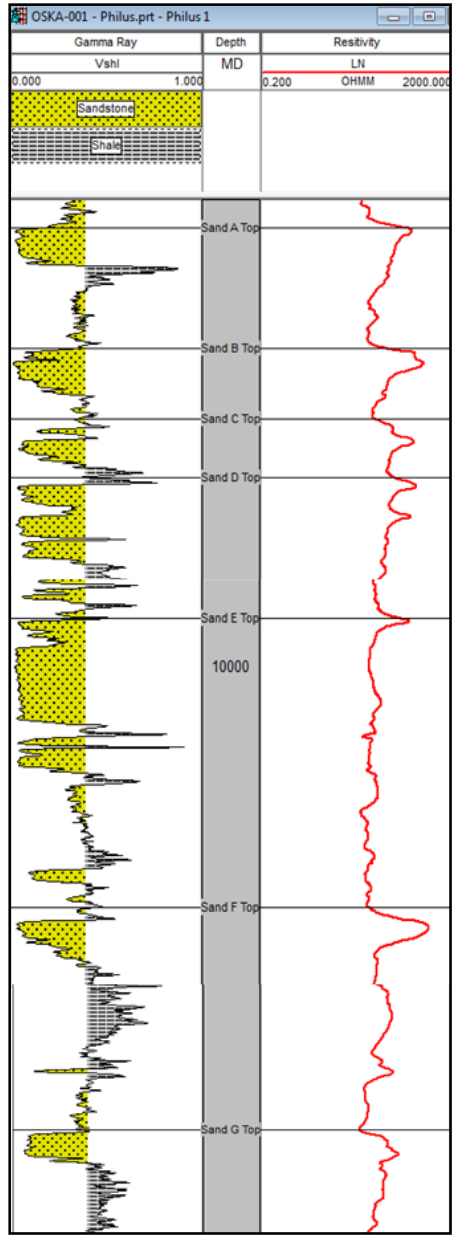

Fig. 5: Reservoir Mapping of Philus Field

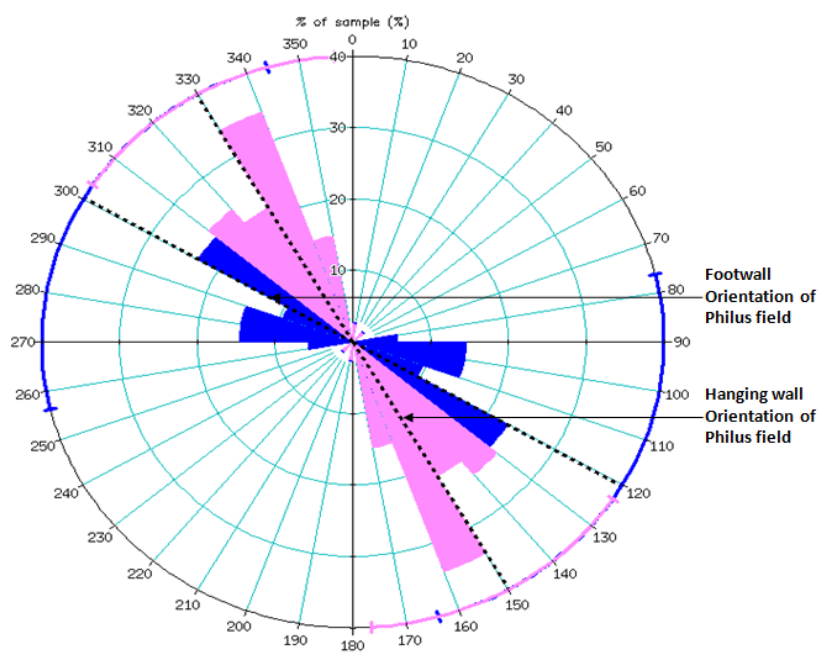

Fig. 6: Fault Orientation on the Investigated Fields (Strike: NW-SE, Dip: S). 


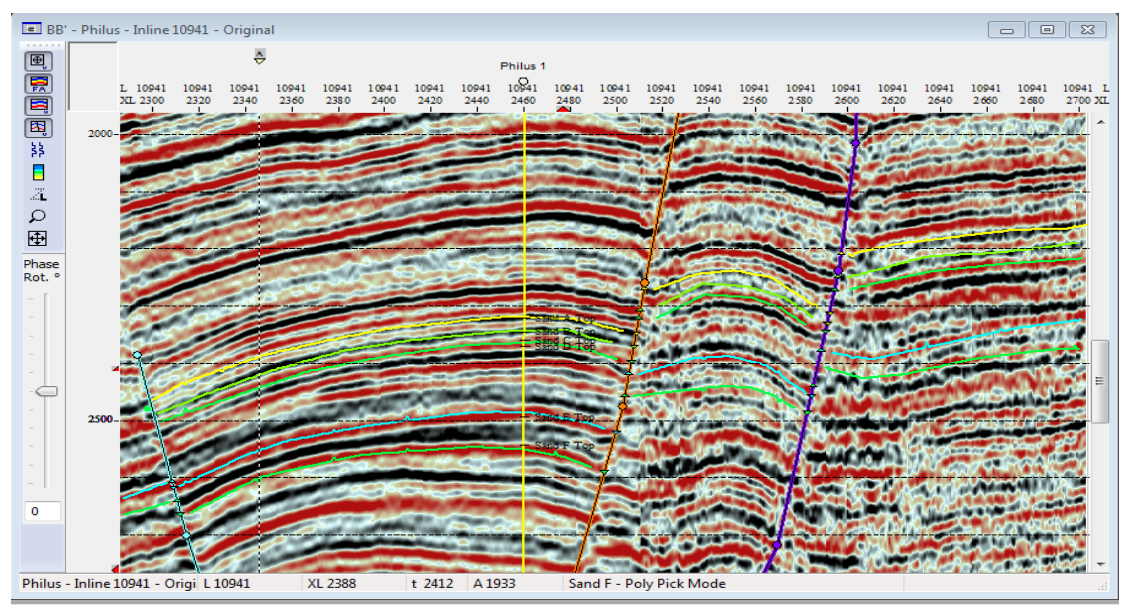

Fig. 7a: Inline 10941 of Interpreted Horizons at Philus Field.

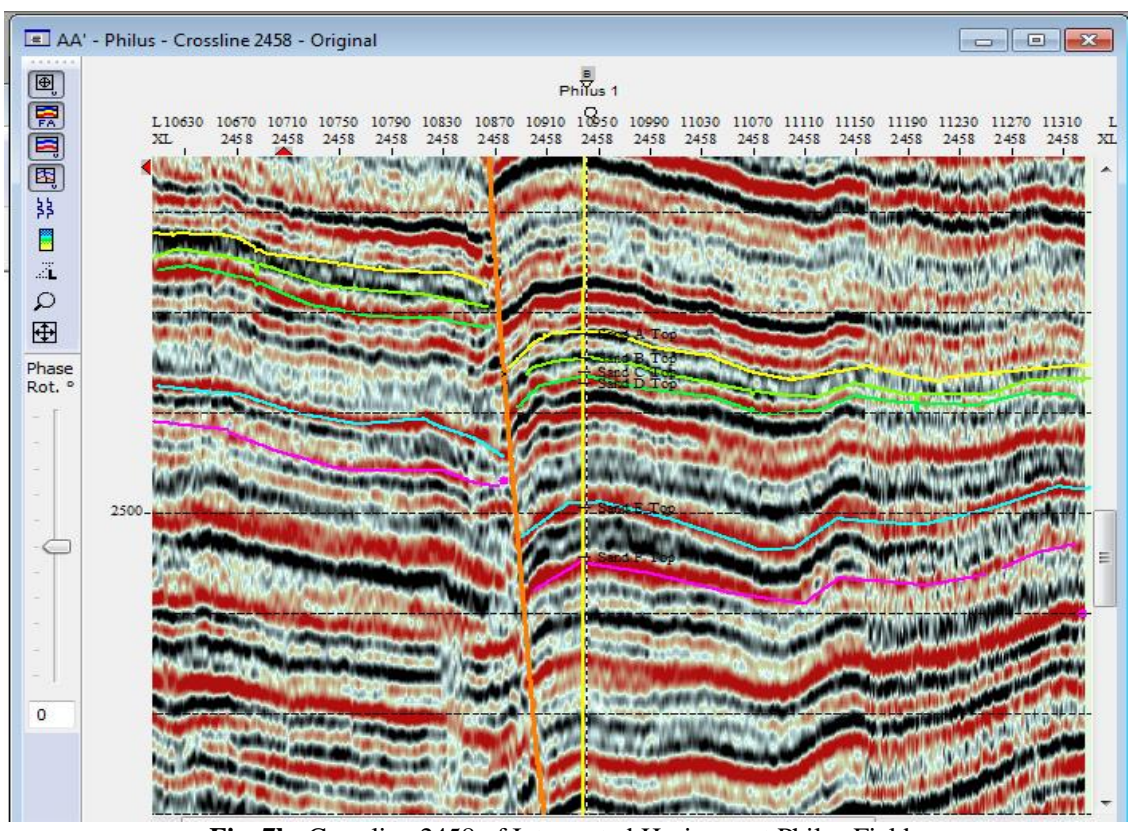

Fig. 7b: Crossline 2458 of Interpreted Horizons at Philus Field.

\subsection{Seismic structural maps}

After seismic interpretation has been completed, fault heaves were calculated from the interpretation and the fault polygons were generated from the resulting heaves. The horizon time maps were gridded using the Seisvision gridding algorithm and the grids were exported to Geoatlas for the generation of the time structure map. These time structure maps with the check shots velocity data supplied were used to convert the seismic data from time to depth structures.

The time and depth structure maps were generated in order to estimate the hydrocarbon potential of the field. The time structure map was first generated and the depth structural map was later generated using the equations from velocity model of each well. The time map shows the variation in time across the field while the depth map was used to analyze existing structures. Depth map was also used to locate and calculate the prospect areas.

Time structure maps were generated by joining lines of equal times on the base maps. It is a fault dependent structure. Seven (7) time maps were generated from Philus field (Figure 8a to Figure $8 \mathrm{~g})$.

The time map of sand A to sand G in Philus field have the time interval of $10 \mathrm{~ms}$ on the regular contour while the interval on the bold contour was $50 \mathrm{~ms}$. Sand A (Figure 8a) has a major fault and two minor faults. The time ranged from $2050 \mathrm{~ms}$ to $2450 \mathrm{~ms}$ and the fault trend in NW-SE direction. Sand B (Figure 8b) has a major fault and a minor fault. The time ranged from $2130 \mathrm{~ms}$ to 2470 ms. The fault also trend in NW-SE direction. Sand C (Figure 8c) has the same trend as that of sand B. The time ranged from 2150 $\mathrm{ms}$ to $2490 \mathrm{~ms}$. Sand D (Figure 8d) has a major fault and a minor fault. The time ranged from $2150 \mathrm{~ms}$ to $2450 \mathrm{~ms}$. Sand A to sand D have related structures. Sand E (Figure 8e) has a major fault and a minor fault on its structure but different from the previous time structure maps. The time ranged from $2230 \mathrm{~ms}$ to $2640 \mathrm{~ms}$. It has series of closures towards the southern part of the sand. Sand F (Figure 8f) has similar structure to that of sand E. Sand F time ranged from $2280 \mathrm{~ms}$ to $2710 \mathrm{~ms}$. Sand G (Figure 8g) has a major fault and a minor fault also. The time ranged from $2590 \mathrm{~ms}$ to $3000 \mathrm{~ms}$. 


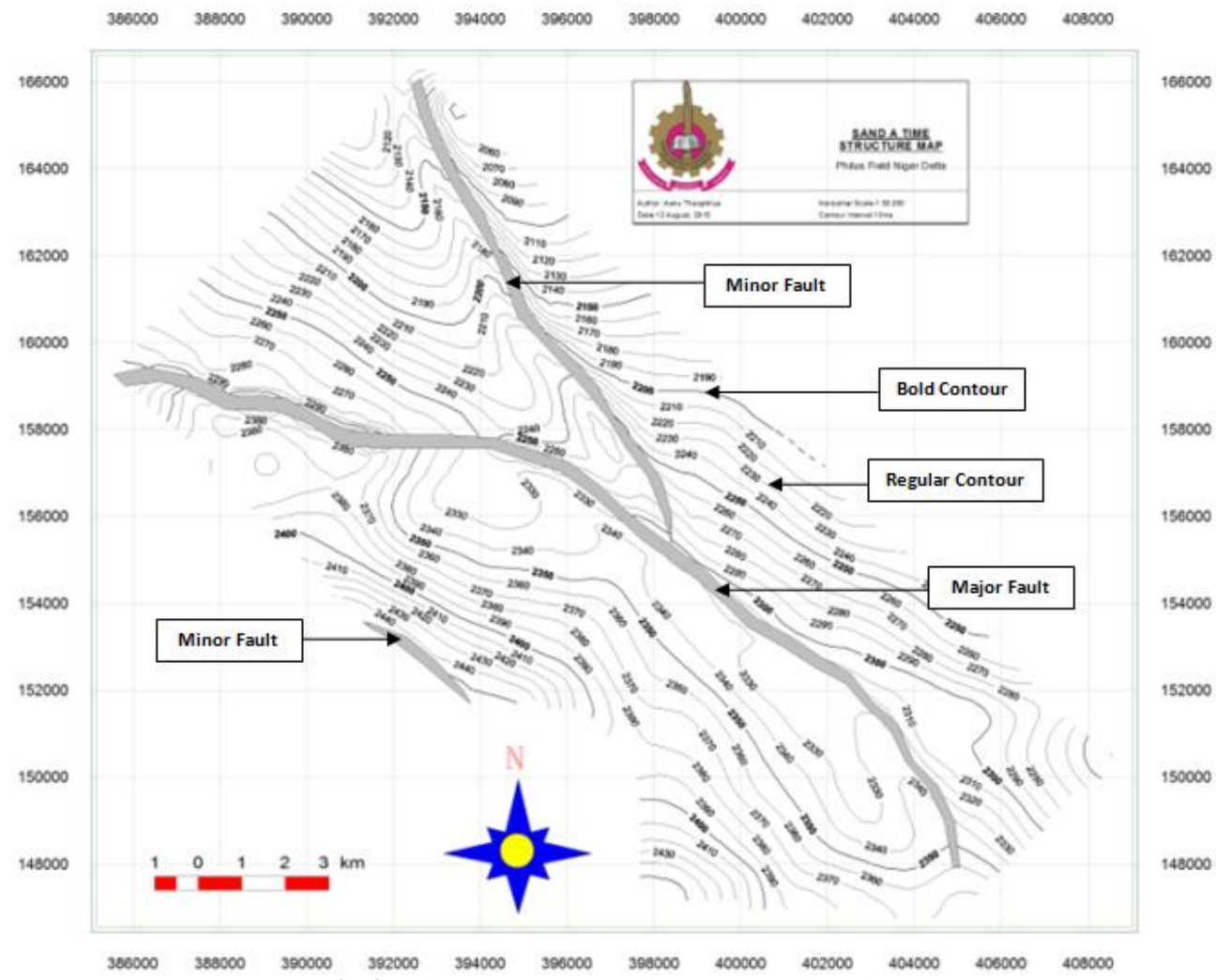

Fig. 8a: Time Structure Map of Sand A on Philus Field.

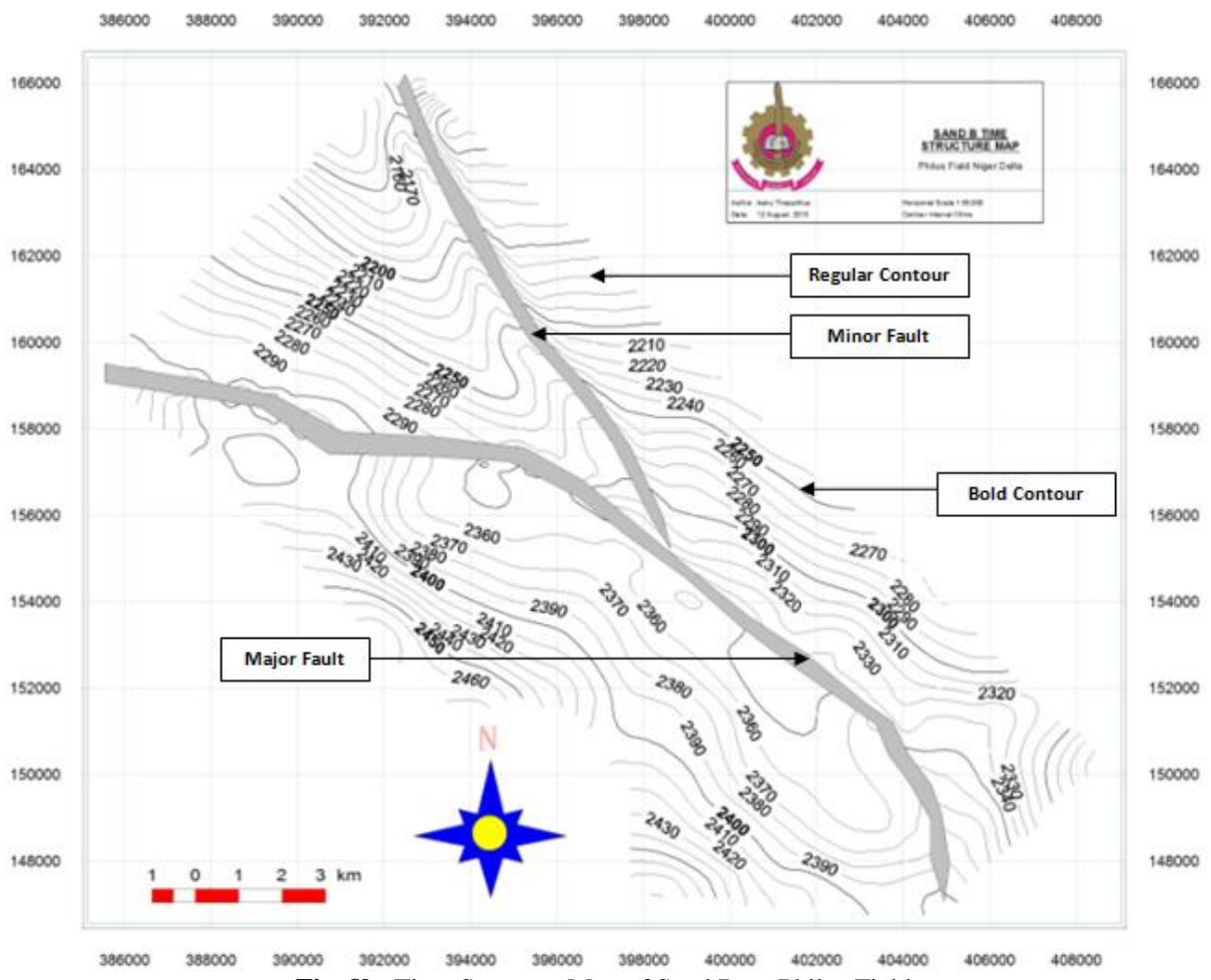

Fig. 8b: Time Structure Map of Sand B on Philus Field. 


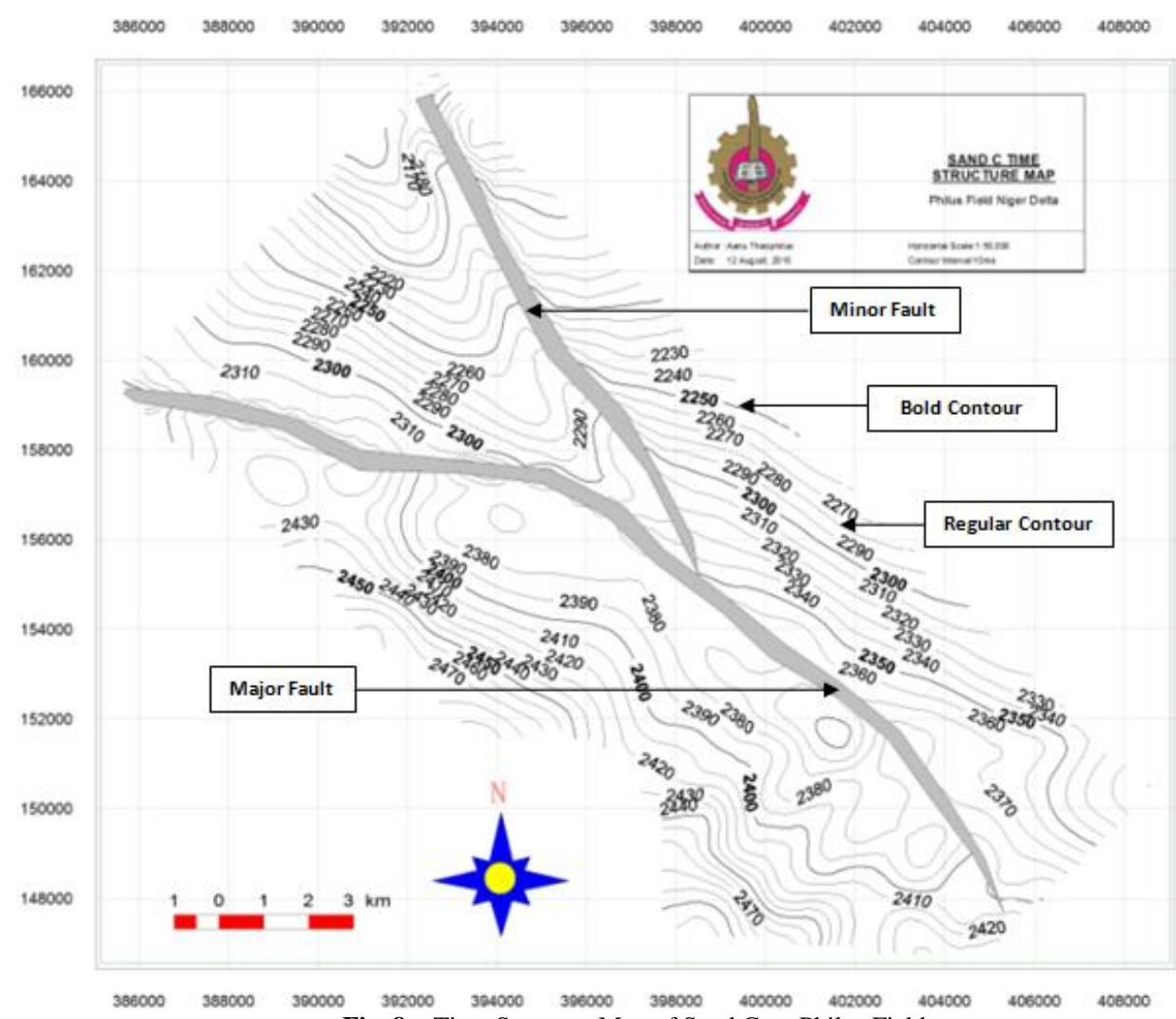

160000

164000

162000

160000

150000

156000

154000

152000

150000

148000

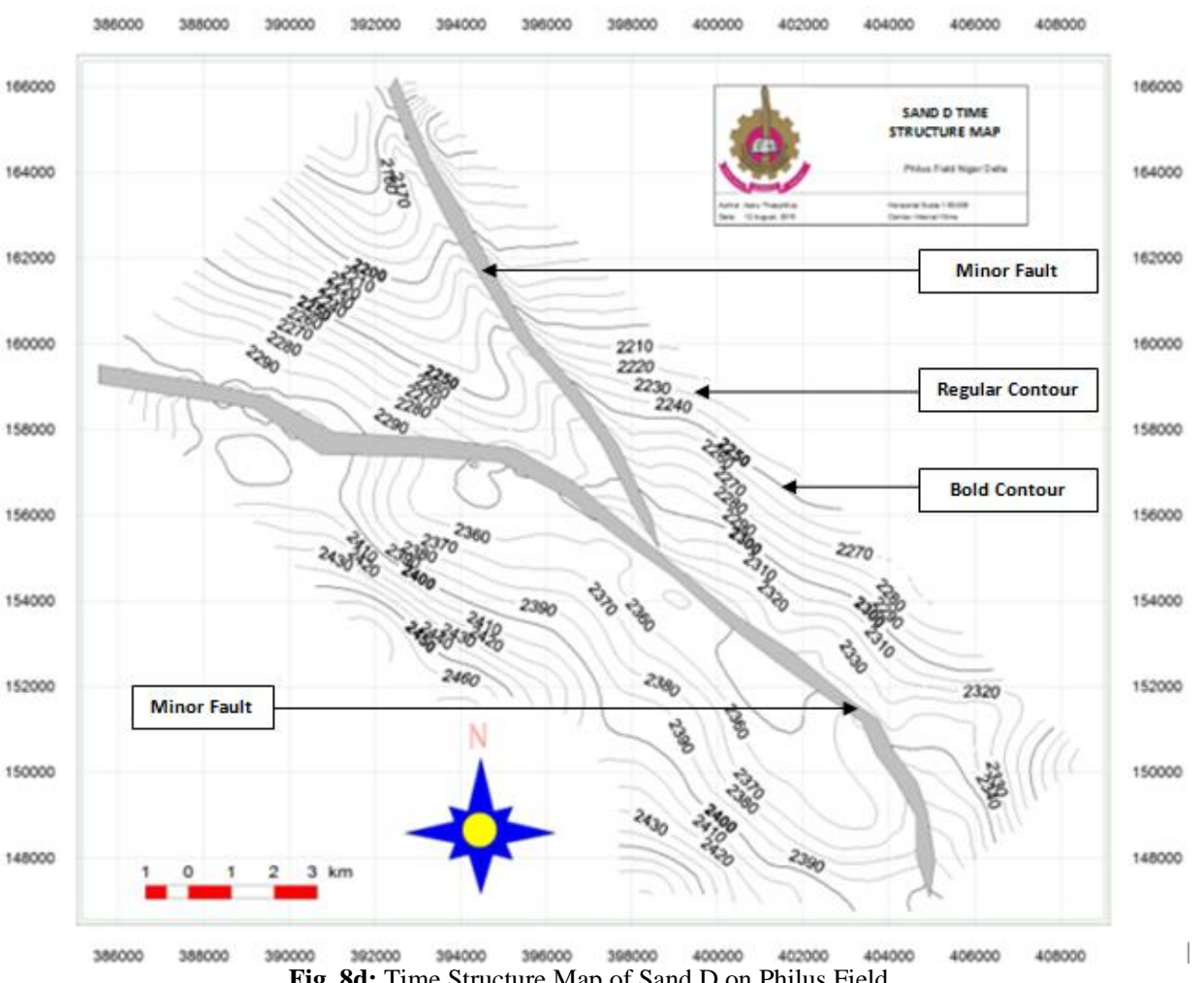




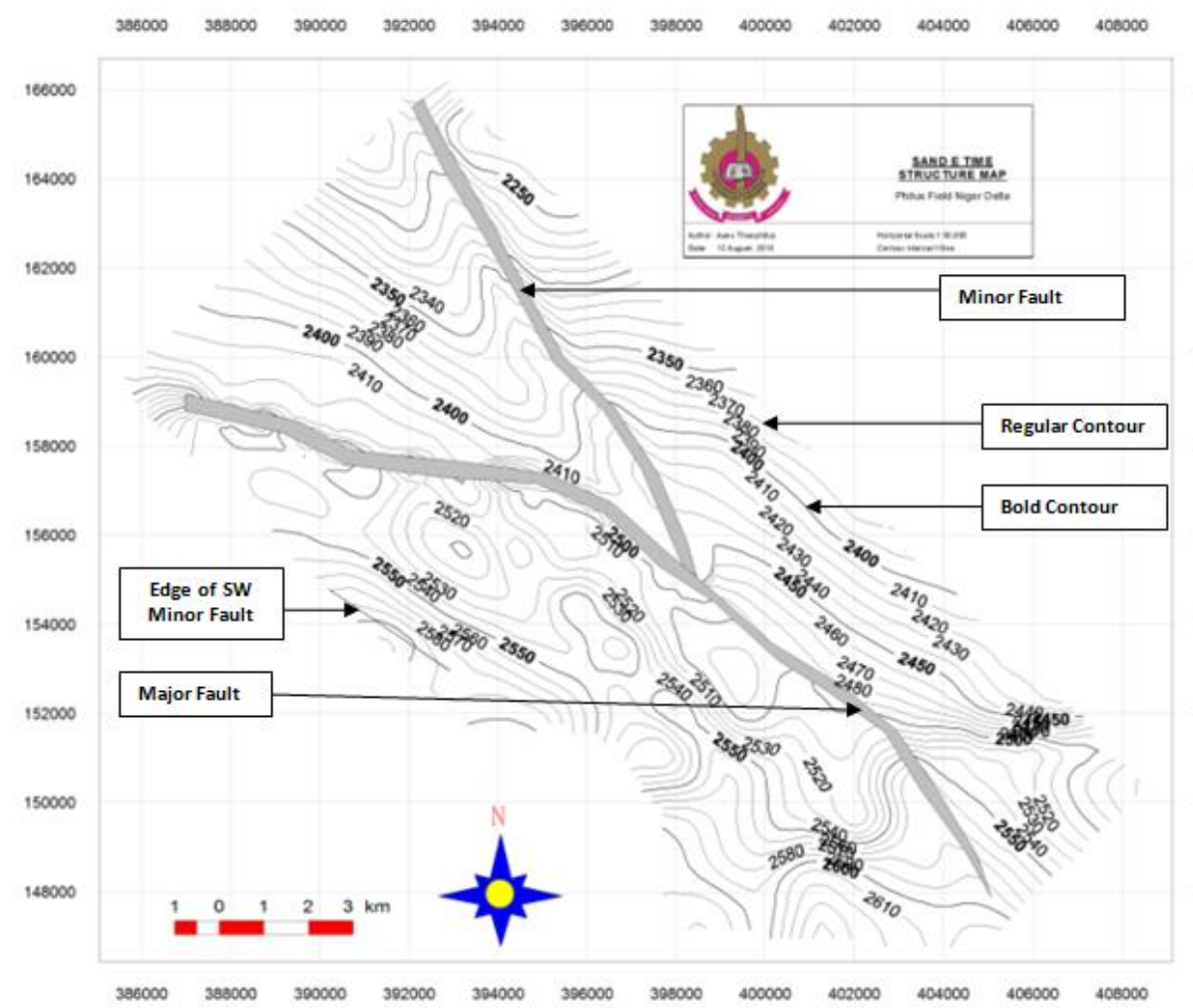

160000

164000

162000

160000

158000

150000

154000

152000

150000

148000

Fig. 8e: Time Structure Map of Sand E on Philus Field.

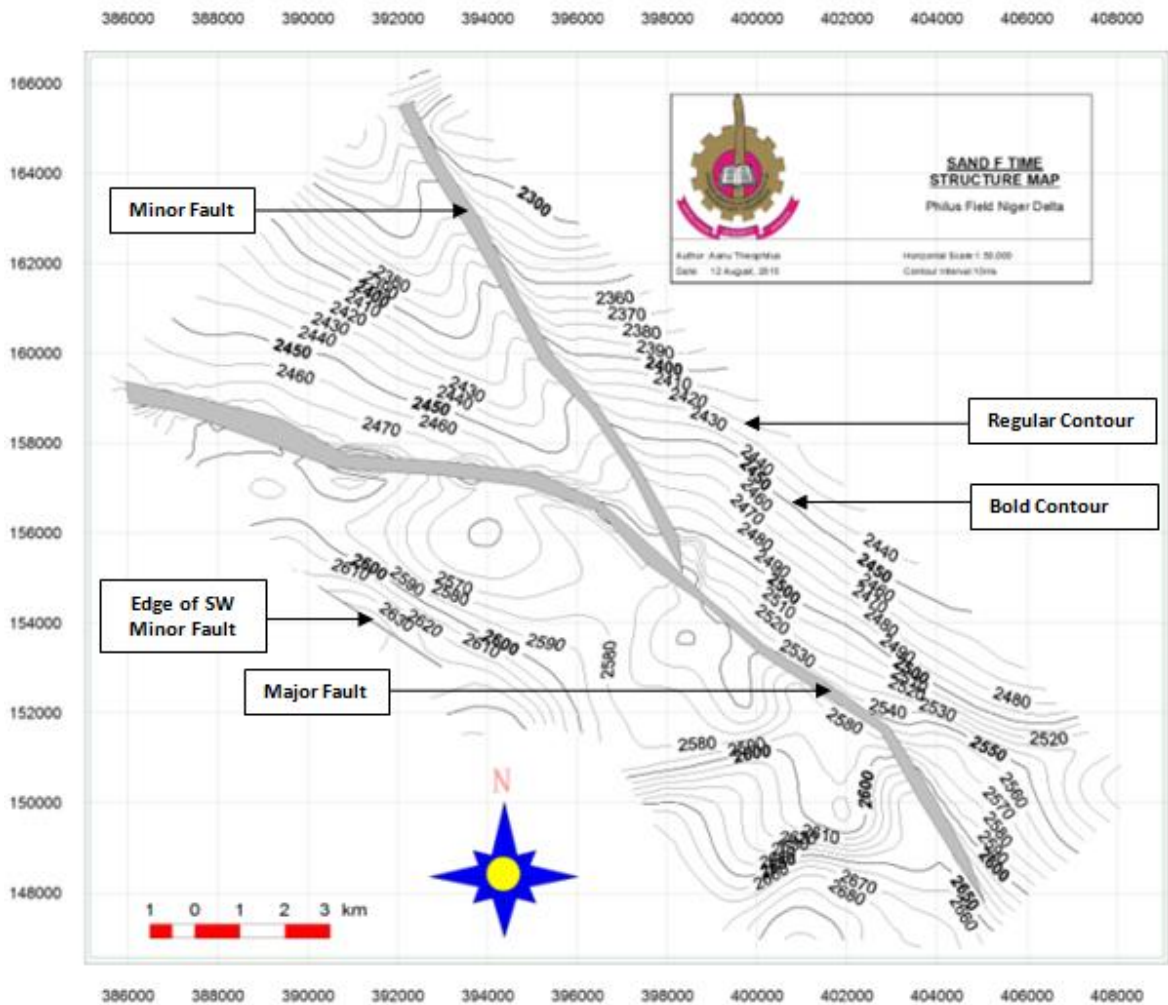

166000

164000

162000

160000

158000

156000

154000

152000

150000

148000

Fig. 8f: Time Structure Map of Sand F on Philus Field. 


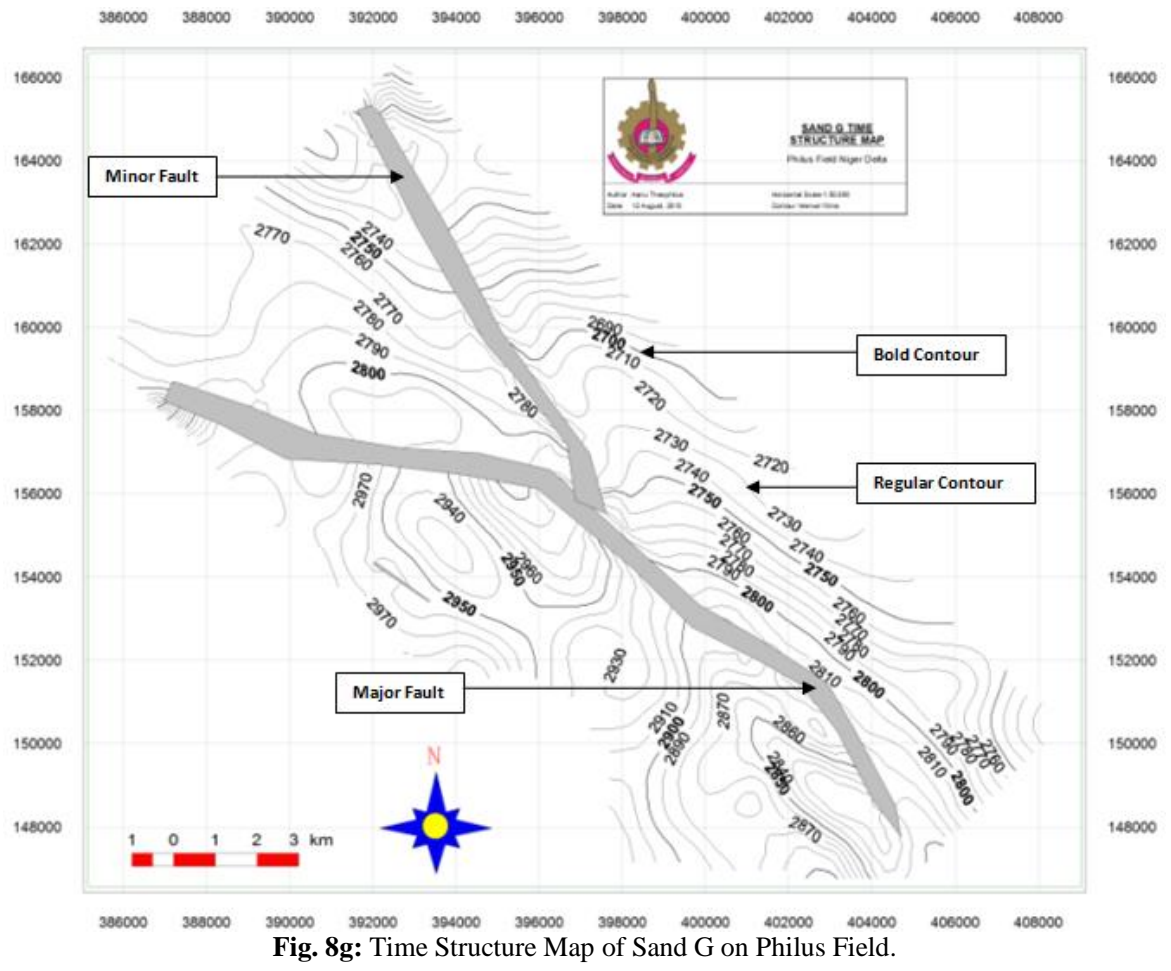

To generate the depth map, velocity model is developed. It makes use of check shots data (a type of borehole seismic data designed to measure the seismic travel time from the surface to a known depth) and converts each individual value of time into depth. This is necessary because the drillers are interested in depth when ready to drill in the formation during production of hydrocarbon. However, since seismic data was recorded in time, there is a need to convert the values extracted in time to depth. Basically, what is done is that, True Vertical Depth (TVD) is plotted against TwoWay-Travel time (TWT). The models gotten from the graph was used for the conversion such that when x-value (time) is known, its corresponding $y$-value (depth) could be determined using the polynomial equations. Regression analysis of each graph was also determined in order to know the level of acceptance of the model. However, the model for Philus field was $\mathrm{y}=-0.0007 \mathrm{x}^{2}-2.1782$ xs - 396.63 while it's R-square was 1 (Figure 9).

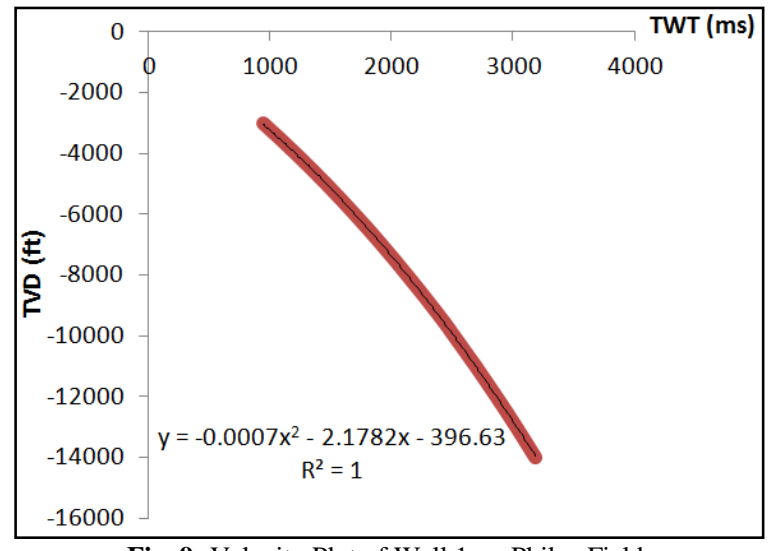

Fig. 9: Velocity Plot of Well 1 on Philus Field.

Depth structure maps were generated using the velocity models from individual well on the two fields investigated. The map depicts the depth to the top of the prospective reservoirs at different locations. It is observed that close contours could represent traps for hydrocarbon content as delineated by the petroleum system of the Niger-Delta region. Most of the traps of the Niger-Delta are fault dependent, hence, more interest lie on areas where there is a contour closing on a fault and characterized by a peak in resistivity on the resistivity log. Seven (7) depth maps were generated at Philus field (Figure 10a to Figure 10g).
Horizon A of Philus field (Figure 10a) has one discovered (red colour) region and one new prospect (yellow colour). The two closures were fault dependent while the closures are formed at the hanging wall of the major fault. No closure was identified on minor fault. A fault independent closure was located towards the southeastern region of horizon A. Apart from the fact that the closure was too small, it is fault independent. However, further analysis is unnecessary.

The structures on the depth map of sand A (Figure 10a) were similar to that of time structure map of horizon A of Philus field (Figure $8 \mathrm{a}$ ). The previously deduced faults and the direction of the faults were clearly seen. The depth map has contour interval of 50 $\mathrm{ft}$. the discovery and the new prospect were anticline which is the best zone of interest for this study. The discovery and the new prospect have contour line $9050 \mathrm{ft}$ closing up with the major fault respectively.

The structures on the depth map of sand B to sand G (Figure 10b to Figure $10 \mathrm{~g}$ ) were all similar to those observed on their time structure maps (Figure 8b to Figure 8g). Horizon B to horizon G (Figure $10 \mathrm{~b}$ to Figure $10 \mathrm{~g}$ ) all have the discovery zones and the new prospect zones. Horizon E discovery was named unyielding discovery because the resistivity of that reservoir on well logs was too low. This was also confirmed from the production record of Philus field. All the prospects were fault dependent on major fault of the field. The previously deduced faults on respective time structure maps were clearly seen on the depth maps. The depth map of horizon B to horizon $\mathrm{G}$ have contour interval of $50 \mathrm{ft}$. All the prospects were anticline (even the unyielding discovery). The contour line of horizon B both at discovery and the new prospect was $9180 \mathrm{ft}$ closing up with the fault, horizon $\mathrm{C}$ has contour line of $9250 \mathrm{ft}$ closing up with the fault, horizon D has contour line of $9300 \mathrm{ft}$ closing up with the fault, horizon E has contour line of $9900 \mathrm{ft}$ at the new prospect while the discovery has been identified as unyielding zone, horizon F has contour line of $10300 \mathrm{ft}$ at the discovery while that of the new prospect was $10050 \mathrm{ft}$.

The depth map of horizon $\mathrm{G}$ (Figure $10 \mathrm{~g}$ ) resembles its time map (Figure $8 \mathrm{~g}$ ). Between the minor fault and the major fault of horizon $\mathrm{G}$, a very big prospect seemed to emerge at $11859 \mathrm{ft}$, this zone is interpreted as syncline. Therefore, hydrocarbon could not be trapped there. The map has contour interval of $50 \mathrm{ft}$, the horizon ranged from the depth of $10000 \mathrm{ft}$ to $12700 \mathrm{ft}$. The discovery was mapped at $12550 \mathrm{ft}$ while the new prospect was mapped at 12050 $\mathrm{ft}$. 

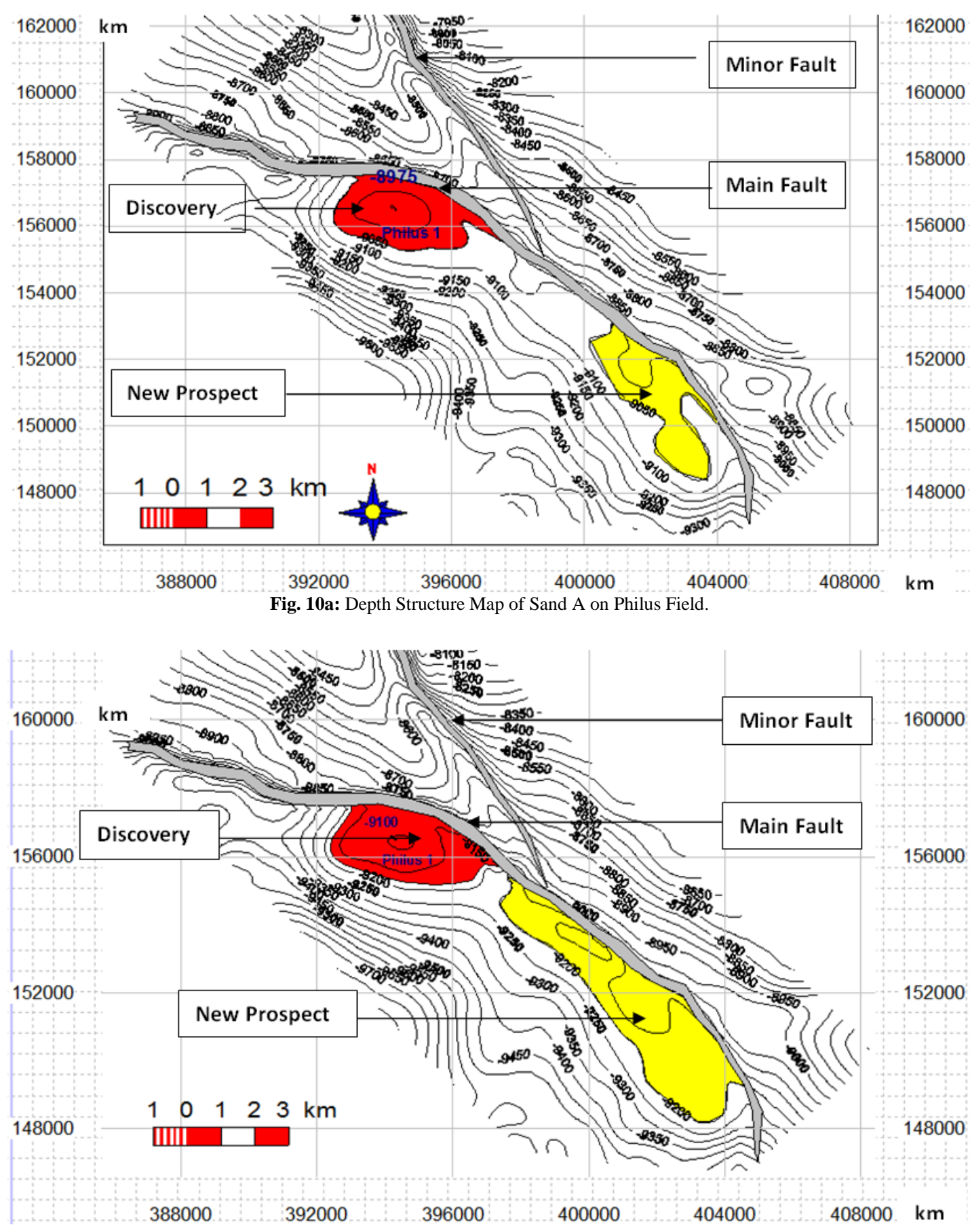

Fig. 10b: Depth Structure Map of Sand B on Philus Field. 


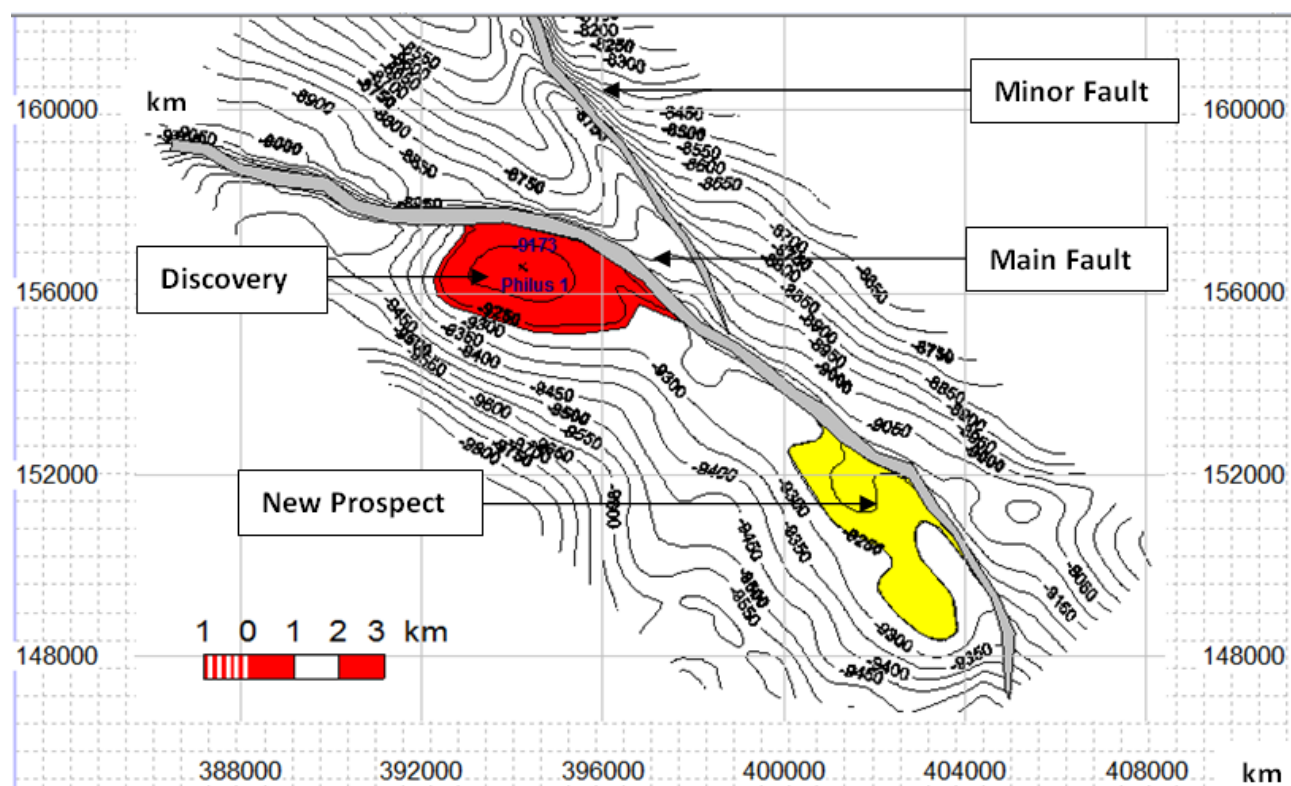

Fig. 10c: Depth Structure Map of Sand C on Philus Field.

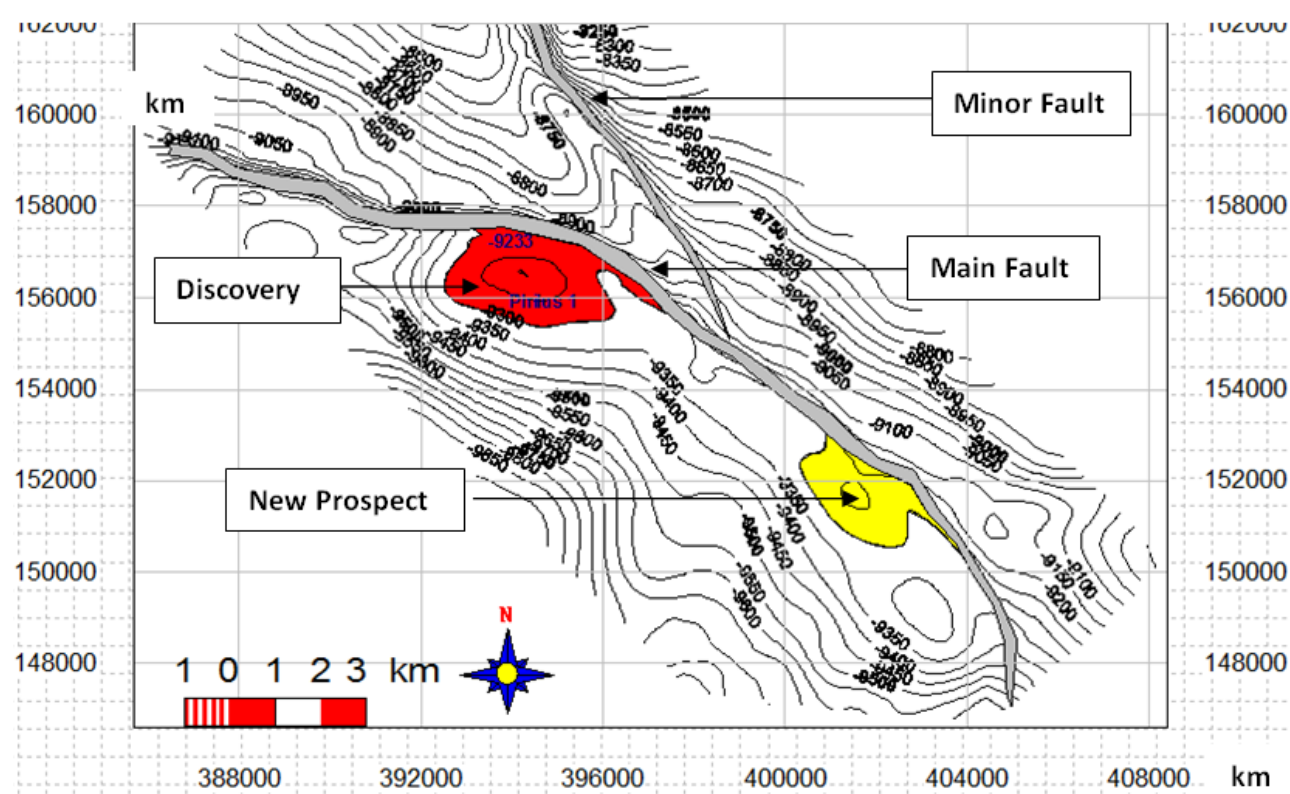

Fig. 10d: Depth Structure Map of Sand D on Philus Field.

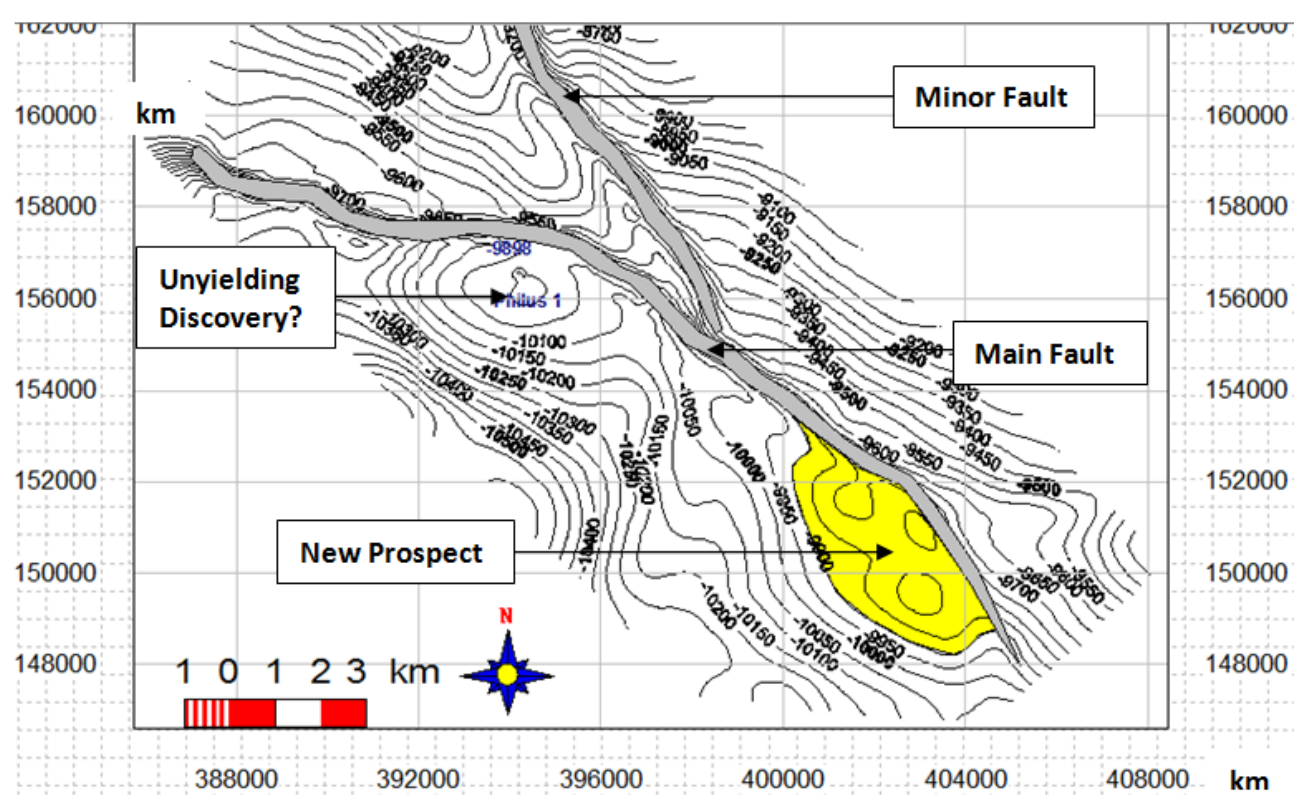

Fig. 10e: Depth Structure Map of Sand E on Philus Field. 


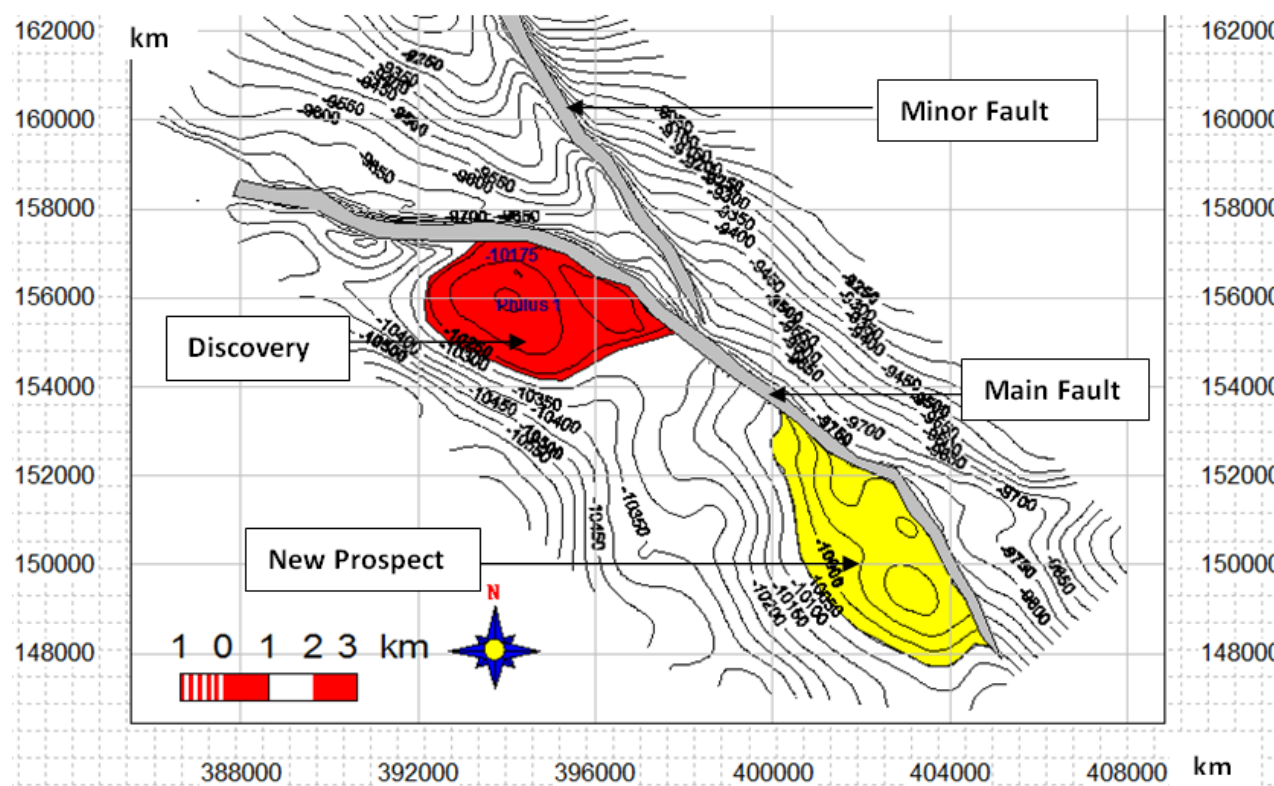

Fig. 10f: Depth Structure Map of Sand F on Philus Field.

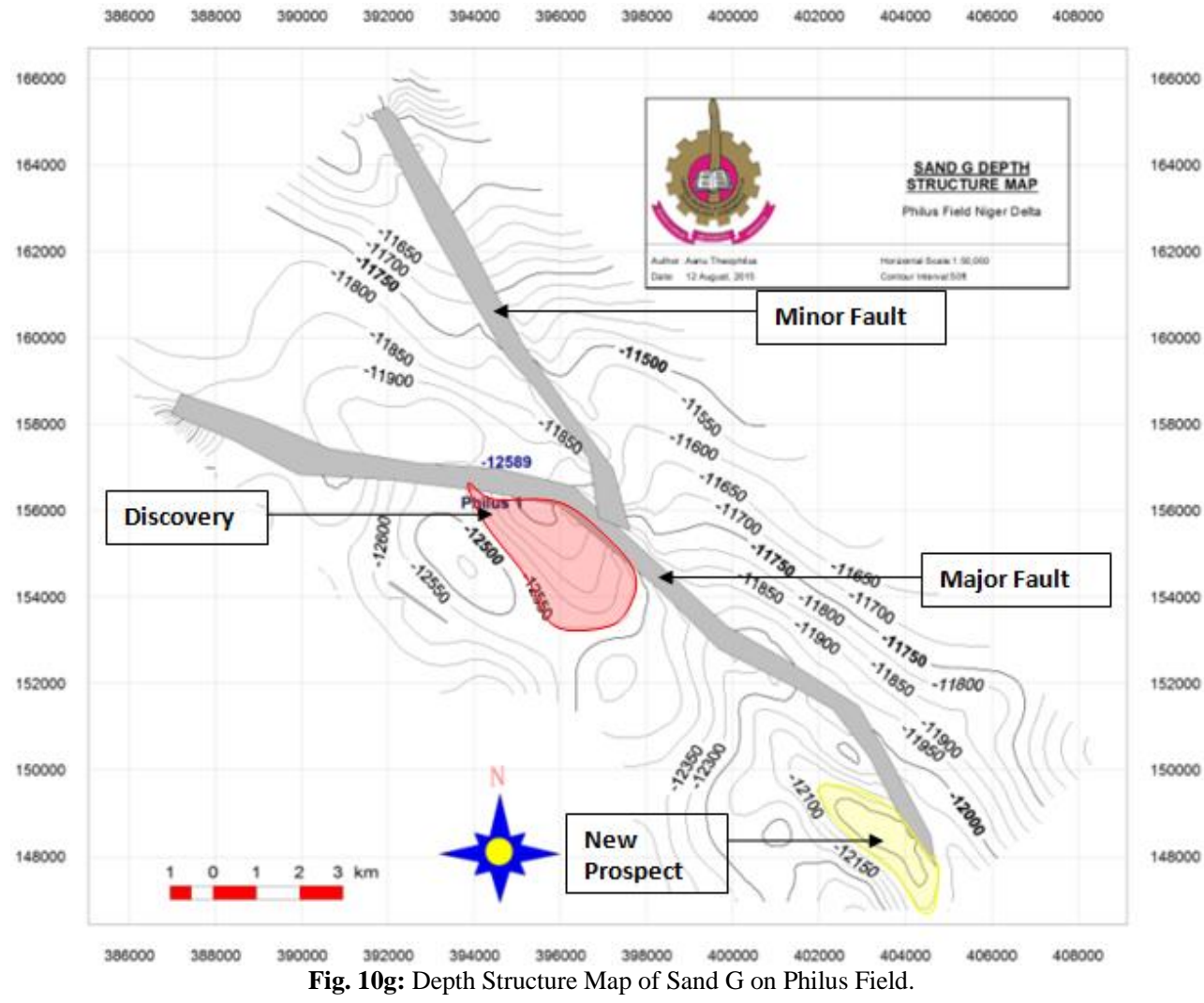

\subsection{Petrophysical and volumetric analyses}

The results of the interpreted well logs revealed that the hydrocarbon interval in the areas occurred between the depths range of $8850 \mathrm{ft}(2681.8 \mathrm{~m})$ to $12580 \mathrm{ft}(3812.1 \mathrm{~m})$. From the analysis, it was discovered that Philus was oil field. Based on the analysis, five (5) hydrocarbon bearing zones were identified on the discovery zone of Philus field. However, appraisal well of Philus 1 was used for the petrophysical analysis of the new prospect trap on Philus field. Six (6) hydrocarbon bearing zones were discovered on the new prospect trap. Results of Petrophysical parameters and volumetric analysis of Philus 1 (discovery) and the new prospect were presented on Table $1 \mathrm{a}$ and Table $1 \mathrm{~b}$ respectively.

The porosity and the net to gross of Philus 1 and new prospect were 0.24 and 0.76 respectively. 42, 173, 965 bbl of oil was estimated as stock original oil in place at sand A, 4, 809, $788 \mathrm{bbl}$ at sand $\mathrm{B}, 8,375,915 \mathrm{bbl}$ at sand $\mathrm{C}, 1,561,025 \mathrm{bbl}$ at sand $\mathrm{D}$, while sand $\mathrm{F}$ has 43, 145, $922 \mathrm{bbl}$ of oil at the discovery zone of Philus 1. Sand $E$ and sand $G$ were non-hydrocarbon bearing sands on Philus 1 (Table 1a). However, the Stock Tank Original Oil in Place of the new prospect is as follow: $27,634,598 \mathrm{bbl}$ at sand A, 61, 684, $580 \mathrm{bbl}$ at sand B, 28, 182, $468 \mathrm{bbl}$ at sand C, 18, 106, $754 \mathrm{bbl}$ at sand D, 114, 483, $819 \mathrm{bbl}$ at sand $\mathrm{E}$, and 211, 313, 416 bbl at sand F. Sand G was non-hydrocarbon bearing sands on the new prospect (Table 1b). The volumetric analysis revealed that new prospect trap has more pay than the discovery trap. 
Table 1a: Petrophysical Parameters and Volumetric Analysis of Philus 1 (Discovery).

\begin{tabular}{|c|c|c|c|c|c|c|c|}
\hline Sands & $\begin{array}{l}\text { Area } \\
\text { (Acres) }\end{array}$ & $\begin{array}{l}\text { GRV } \\
\text { (Acreft) }\end{array}$ & NTG & $\begin{array}{l}\text { Porosity } \\
(\varphi)\end{array}$ & Sw & $\begin{array}{l}\text { OOIP } \\
\text { (bbl) }\end{array}$ & $\begin{array}{l}\text { STOOIP } \\
\text { (bbl) }\end{array}$ \\
\hline $\begin{array}{l}\text { Sand } \\
\text { A }\end{array}$ & $\begin{array}{l}1, \\
580.16\end{array}$ & $\begin{array}{l}59, \\
896.6\end{array}$ & 0.76 & 0.24 & 0.40 & $\begin{array}{l}50, \\
608, \\
758\end{array}$ & $\begin{array}{l}42,173, \\
965\end{array}$ \\
\hline $\begin{array}{l}\text { Sand } \\
\text { B }\end{array}$ & 501.77 & $\begin{array}{l}6, \\
830.99\end{array}$ & 0.76 & 0.24 & 0.40 & $\begin{array}{l}5, \\
771, \\
745\end{array}$ & $\begin{array}{l}4,809 \\
788\end{array}$ \\
\hline $\begin{array}{l}\text { Sand } \\
\text { C }\end{array}$ & 689.075 & $\begin{array}{l}11, \\
895.7\end{array}$ & 0.76 & 0.24 & 0.40 & $\begin{array}{l}10, \\
051, \\
098\end{array}$ & $\begin{array}{l}8,375, \\
915\end{array}$ \\
\hline $\begin{array}{l}\text { Sand } \\
\text { D }\end{array}$ & 269.245 & $\begin{array}{l}2, \\
217.01\end{array}$ & 0.76 & 0.24 & 0.40 & $\begin{array}{l}1, \\
873, \\
230\end{array}$ & $\begin{array}{l}1,561, \\
025\end{array}$ \\
\hline $\begin{array}{l}\text { Sand } \\
\text { F }\end{array}$ & $\begin{array}{l}1, \\
389.245\end{array}$ & 61,277 & 0.76 & 0.24 & 0.40 & $\begin{array}{l}51, \\
775, \\
107\end{array}$ & $\begin{array}{l}43,145 \\
922\end{array}$ \\
\hline
\end{tabular}

Table 1b: Petrophysical Parameters and Volumetric Analysis of New Prospect.

\begin{tabular}{|c|c|c|c|c|c|c|c|}
\hline Sands & $\begin{array}{l}\text { Area } \\
\text { (Acres) }\end{array}$ & $\begin{array}{l}\text { GRV } \\
\text { (Acreft) }\end{array}$ & NTG & $\begin{array}{l}\text { Porosity } \\
(\varphi)\end{array}$ & Sw & $\begin{array}{l}\text { OOIP } \\
\text { (bbl) }\end{array}$ & $\begin{array}{l}\text { STOOIP } \\
\text { (bbl) }\end{array}$ \\
\hline $\begin{array}{l}\text { Sand } \\
\text { A }\end{array}$ & $\begin{array}{l}1, \\
572.97\end{array}$ & $\begin{array}{l}39, \\
247.4\end{array}$ & 0.76 & 0.24 & 0.40 & $\begin{array}{l}33, \\
161, \\
518\end{array}$ & $\begin{array}{l}27,634, \\
598\end{array}$ \\
\hline $\begin{array}{l}\text { Sand } \\
\text { B }\end{array}$ & $\begin{array}{l}2, \\
397.16\end{array}$ & $\begin{array}{l}87, \\
606.1\end{array}$ & 0.76 & 0.24 & 0.40 & $\begin{array}{l}74, \\
021, \\
496\end{array}$ & $\begin{array}{l}61,684, \\
580\end{array}$ \\
\hline $\begin{array}{l}\text { Sand } \\
\text { C }\end{array}$ & $\begin{array}{l}1, \\
594.17\end{array}$ & $\begin{array}{l}40, \\
025.5\end{array}$ & 0.76 & 0.24 & 0.40 & $\begin{array}{l}33, \\
818, \\
962\end{array}$ & $\begin{array}{l}28,182 \\
468\end{array}$ \\
\hline $\begin{array}{l}\text { Sand } \\
\text { D }\end{array}$ & $\begin{array}{l}1, \\
142.54\end{array}$ & $\begin{array}{l}25, \\
715.7\end{array}$ & 0.76 & 0.24 & 0.40 & $\begin{array}{l}21, \\
728, \\
105\end{array}$ & $\begin{array}{l}18,106 \\
754\end{array}$ \\
\hline $\begin{array}{l}\text { Sand } \\
\text { E }\end{array}$ & $\begin{array}{l}2, \\
586.15\end{array}$ & $\begin{array}{l}162, \\
593\end{array}$ & 0.76 & 0.24 & 0.40 & $\begin{array}{l}137, \\
380, \\
582\end{array}$ & $\begin{array}{l}114, \\
483,819\end{array}$ \\
\hline $\begin{array}{l}\text { Sand } \\
\text { F }\end{array}$ & $\begin{array}{l}3, \\
154.26\end{array}$ & $\begin{array}{l}300 \\
113\end{array}$ & 0.76 & 0.24 & 0.40 & $\begin{array}{l}253 \\
576, \\
099\end{array}$ & $\begin{array}{l}211, \\
313,416\end{array}$ \\
\hline
\end{tabular}

Hint: GRV is the Gross Rock Volume, NTG is the Net to Gross, Sw is the water saturation, OOIP is the Original Oil in Place, and STOOIP is the Stock Tank Original Oil in Place.

\section{Conclusion}

The 3-D seismic and well log data have been used to characterize reservoirs and analyze the by-passed pay of Philus field, Niger Delta, Nigeria. This was done by producing structural maps from the combination of seismic and well log data in order to analyze the pay of Philus field. The computed petrophysical parameters showed that Philus field has porosity values that could hold appreciable volume of hydrocarbons for production. The STOOIP of discovery trap in Philus field ranged from 1.6 to 43.1 Mbbl while that of new prospect trap ranged from 18.1 to $211.3 \mathrm{Mbbl}$. New prospect trap was the only identified by-passed pay mapped from the study area. It was discovered that new prospect trap has more pay than the discovery trap of Philus field. From the two traps in Philus field (discovery and new prospect traps), sand E and sand $G$ were non-hydrocarbon bearing sands in former while sand $\mathrm{G}$ was only analyzed to be non-hydrocarbon bearing sand in later trap. This study has been able to provide additional information about oil reserve in Philus field and also give precise direction for well placement (that is, new prospect trap) in further exploration and production of hydrocarbon in the study area.

It is recommended that the oil reserve of Philus field needs to be recalculated. Also, the new prospect trap is recommended for hydrocarbons' exploitation since it has more pay than the discovery trap.

\section{Acknowledgements}

The authors are grateful to the assistance rendered by the Department of Petroleum Resources, Ministry of Petroleum Resources,
Nigeria and Nigerian Petroleum Development Company for providing the data used for this study. The constructive criticisms of the reviewers of this journal are also appreciated. Furthermore, Adagunodo T.A. (one of the authors) is grateful to the Board of Postgraduate School, LAUTECH for the provision of Teaching Assistantship award given in order to complete this research.

\section{References}

[1] Adaeze, I. Ulasi, Samuel, O. Onyekuru and Cajetan, J. Iwuagwu (2012). Petrophysical evaluation of Uzek well using well log and core data, Offshore Depobelt, Niger Delta, Nigeria. Advances in Applied Science Research, 3(5), 2966-2991.

[2] Ameloko, A.A. and Omali, A.O. (2013). Reservoir Characterization and Structural Interpretation of Seismic Profile: a case study of Zfield, Niger Delta, Nigeria. Petroleum and Coal, 55(1), 37-43.

[3] Anyiam, O.A.; Mode, A.W. and Ekwe, A.C. (2010). Formation evaluation of an onshore appraisal well 'KG-5', "Green Field", Niger Delta, Nigeria. American Journal of Scientific and Industrial Research, $1(2)$, http://dx.doi.org/10.5251/ajsir.2010.1.2.262.270.

[4] Asquith, G. and Gibson, C. (1982). Basic well log analysis for geologists. $A A P G$, Tulsa, $\mathrm{OK}$.

[5] Doust, H.; and Omatsola, E. (1990). Niger Delta, in, Edwards, J.D. and Santogrossi, P.A., eds., Divergent/Passive Margin Basins, AAPG Memoir 48, Tulsa, American Association of Petroleum Geologists, 239-248.

[6] Egbai, J.C.; Ihianle, O.E. and Aigbogun, C.O. (2012). Reservoir and mathematical modellings for calculating hydrocarbon in place using well log data. Elixir Pollution, 43, 6978-6981.

[7] Eshimokhai, S. and Akhirevbulu, O.E. (2012). Reservoir characterization using seismic and well logs data (a case study of Niger Delta). Ethiopian Journal of Environmental Studies and Management, $\quad 5(4), \quad$ (suppl.2), 597-603. http://dx.doi.org/10.4314/ejesm.v5i4.s20.

[8] Kulke, H. (1995). Nigeria, in, Kulke, H., ed., Regional Petroleum Geology of the World. Part II: Africa, America, Australia and Antarctica. Berlin, Gebrüder Borntraeger, 143-172.

[9] Muslime, B.M. and Moses, A.O. (2011). Reservoir Characterization and Paleo-Stratigraphic imaging over Okari Field, Niger Delta using neutral networks; The Leading Edge, 1(6), 650 -655.

[10] Nwachukwu, S.O. and Chukwura, P.I. (1986). Organic matter of Agbada Formation, Niger Delta, Nigeria. AAPG Bulletin, 70, 48-55.

[11] Ologe, O.; Ola-Buraimo, A.O. and Bankole, S.A. (2013). 3D Seismic structural interpretation of a part of Aloo field, Southwestern Niger Delta, Nigeria. IOSR Journal of Applied Geology and Geophysics, 1(1), 29-35. http://dx.doi.org/10.9790/0990-0112935.

[12] Oyedele, K.F.; Ogagarue, D.O. and Mohammed, D.U. (2013). Integration of 3D Seismic and Well Log Data in the Optimal Reservoir Charaterization of EMI Field, Offshore Niger Delta Oil Province, Nigeria. American Journal of Scientific and Industrial Research,

$$
\text { 4(1), }
$$
http://dx.doi.org/10.5251/ajsir.2013.4.1.11.21.

[13] Schlumberger (1989). Log Interpretation, Principle and Application. Schlumberger Wireline and Testing, Houston Texas, pp. $21-$ 89.

[14] Short, K.C. and Stauble, A.J. (1967). Outline of geology of Niger Delta. AAPG Bulletin, 51, 761-779.

[15] Stacher, P. (1995). Present Understanding of the Niger Delta Hydrocarbon Habitat, In, Oti, M. N., and Postman Eds., Geology of Deltas: Rotterdam, A. A., Balkema, Pg. 257-267.

[16] Tuttle, M.L.W.; Charpentier, R.R. and Brownfield, M.E. (1999). The Niger Delta Basin Petroleum System: Niger Delta Province, Nigeria, Cameroon, and Equatorial Guinea, Africa. Open-file Report 99-50-H. United States Geological Survey, Washington, D.C. 44 . 